\title{
Loss of the anaphase-promoting complex in quiescent cells causes unscheduled hepatocyte proliferation
}

\author{
Karin G. Wirth, ${ }^{1}$ Romeo Ricci, ${ }^{2}$ Juan F. Giménez-Abián, ${ }^{1}$ Shahryar Taghybeeglu, ${ }^{1}$ Nobuaki R. Kudo, ${ }^{1}$ \\ Wolfram Jochum, ${ }^{3}$ Mireille Vasseur-Cognet, ${ }^{4}$ and Kim Nasmyth ${ }^{1,5}$ \\ ${ }^{1}$ Research Institute of Molecular Pathology (IMP), A-1030 Vienna, Austria; ${ }^{2}$ Institute of Physiology, Cardiovascular \\ Research, University of Zürich and Department of Cardiology, University Hospital Zürich, Zürich, Switzerland; ${ }^{3}$ Institute of \\ Clinical Pathology, University Hospital Zürich, CH-8091 Zürich, Switzerland; ${ }^{4}$ ICGM, Faculté Cochin-GDPM, \\ 75014 Paris, France
}

The anaphase-promoting complex or cyclosome $(\mathrm{APC} / \mathrm{C})$ is an ubiquitin protein ligase that together with Cdc20 and Cdh1 targets mitotic proteins for degradation by the proteosome. APC-Cdc20 activity during mitosis triggers anaphase by destroying securin and cyclins. APC-Cdh1 promotes degradation of cyclins and other proteins during $G_{1}$. We show that loss of $A P C / C$ during embryogenesis is early lethal before embryonic day E6.5 (E6.5). To investigate the role of APC/C in quiescent cells, we conditionally inactivated the subunit Apc2 in mice. Deletion of Apc2 in quiescent hepatocytes caused re-entry into the cell cycle and arrest in metaphase, resulting in liver failure. Re-entry into the cell cycle either occurred without any proliferative stimulus or could be easily induced. We demonstrate that the APC has an additional function to prevent hepatocytes from unscheduled re-entry into the cell cycle.

[Keywords: Anaphase-promoting complex; APC; cell cycle; G0; quiescent cells]

Supplemental material is available at http://www.genesdev.org.

Received September 15, 2003; revised version accepted November 10, 2003.

Ubiquitin-mediated proteolysis has crucial roles in a wide variety of biological processes, including mitosis, transcriptional control, regulation of the immune system, signal transduction, and development (Ben-Neriah 2002; Conaway et al. 2002; Harper et al. 2002; Peters 2002). The first step in this form of proteolysis is the covalent attachment of multiple ubiquitin chains to target proteins. This is accomplished by specific ubiquitin protein ligases, many of which have RING-H2-finger domains as part of their catalytic cores (Jackson et al. 2000; Pickart 2001).

One of the first RING-finger ubiquitin protein ligases to be associated with a defined and essential physiological function is the multisubunit anaphase-promoting complex or cyclosome (APC/C; Irniger et al. 1995; King et al. 1995; Sudakin et al. 1995). The APC/C consists of 11 subunits and is essential for destroying proteins during mitosis in all eukaryotic cells (Peters et al. 1996; Zachariae et al. 1996). Two of the APC/C's subunits, Apc2 and Apc11, constitute a catalytic core, which is capable of ubiquitinating target proteins in vitro (Gma-

${ }^{5}$ Corresponding author.

E-MAIL k.nasmyth@nt.imp.univie.ac.at; FAX 0043-1-798-9390.

Article and publication are at http://www.genesdev.org/cgi/doi/10.1101/ $\operatorname{gad} .285404$. chl et al. 2000; Leverson et al. 2000). Apc2 and Apc11 interact with each other and contain cullin homology and RING-finger domains respectively (Yu et al. 1998; Zachariae et al. 1998b; Tang et al. 2001).

The APC/C triggers the onset of anaphase in most if not all eukaryotic cells by inducing the destruction of sister-chromatid cohesion. It performs this by ubiquitinating a protein called securin that is an inhibitory chaperone of a thiol protease called separase. Once activated, separase cleaves the Sccl subunit of a multiprotein complex called cohesin that holds sister chromatids together. The APC/C at the same time triggers exit from mitosis by destroying mitotic cyclins, which are regulatory subunits of the cyclin-dependent kinase Cdk1. Inactivation of the APC/C causes cells from both yeast (Irniger et al. 1995) and Caenorhabditis elegans to arrest in metaphase (Furuta et al. 2000; Golden et al. 2000). The APC/C's ubiquitination of securin and cyclins shortly before the onset of anaphase depends on an unstable regulatory $\beta$-propeller protein called Cdc20 (Visintin et al. 1997), which is destroyed at the end of mitosis (Shirayama et al. 1999). Cdc20 binds the APC/C (Pfleger and Kirschner 2000; Hilioti et al. 2001; Pfleger et al. 2001) and possibly also its target proteins.

The finding that B-type cyclins are rapidly degraded by the APC/C during $G_{1}$ phase raised the possibility that it 
has important functions also in nonmitotic cells (Amon et al. 1994; Brandeis and Hunt 1996; Irniger and Nasmyth 1997). In yeast, the APC/C's activity during $G_{1}$ depends not on Cdc20 but on a related protein called Cdh1 (Visintin et al. 1997; Zachariae et al. 1998a). The activities of $\mathrm{Cdc} 20$ and $\mathrm{Cdh} 1$ are complementary. Whereas Cdc20 is active during mitosis, Cdh1 is active during $G_{1}$, when Cdk1 is inactive. Phosphorylation of Cdh1 by Cdk1 prevents it from binding the APC/C for much of the cell cycle (Schwab et al. 2001). The activities of Cdk1 and APC-Cdh1 are therefore mutually exclusive. The activity of one causes inactivity of the other and vice versa. The functions of APC-Cdh1 during $G_{1}$ are less well understood than those of APC-Cdc20 during mitosis. Inactivation of $\mathrm{Cdh} 1$ or the APC/C causes budding yeast cells to enter $S$ phase in the presence of sex pheromones (Irniger and Nasmyth 1997) and fission yeast cells to do so when starved of a nitrogen source (Kominami et al. 1998). Hyperactivity of Cdk1 due to accumulation of cyclins may be at least partly responsible for these phenomena.

The APC/C is also active in quiescent mammalian cells. Most if not all APC/C subunits as well as Cdh1like proteins are found in tissues composed of fully differentiated cells (Gieffers et al. 1999). Indeed, a fully active complex can be isolated from adult mouse brain tissues. Mammals possess several different Cdh1 proteins, which have different tissue distributions and target specificities (Wan and Kirschner 2001). Loss of a Cdh1 homolog in chicken DT40 cells has little effect on cell proliferation but leads to accumulation of mitotic cyclins in $\mathrm{G}_{1}$ and abrogates $\mathrm{G}_{1}$ arrest mediated by rapamycin (Sudo et al. 2001). In Drosophila, Cdh1 (known as $\mathrm{fzr}$ ) is required when cells exit from the mitotic cycles during embryogenesis and for the destruction of mitotic cyclins in postmitotic embryonic cells (Sigrist and Lehner 1997). The finding that Smad2 binds to Cdh1 and thereby promotes the APC/C's ability to ubiquitinate SnoN, an inhibitor of TGF- $\beta$ signaling, suggests that the APC-Cdh1 might facilitate the antiproliferative effects of TGF- $\beta$ (Stroschein et al. 2001; Wan et al. 2001). However, the physiological significance of this process is not understood.

In this paper we address APC/C's function in quiescent cells using a genetic approach. Instead of identifying potential substrates whose ubiquitination in quiescent cells may be of physiological importance, we generated a conditional allele of $A p c 2$ that permitted us to inactivate this crucial APC/C subunit in nonproliferative tissues. We find that abolition frequently triggers the spontaneous entry into the cell cycle of quiescent hepatocytes. Livers lacking APC/C respond more readily to known proliferative signals.

\section{Results}

\section{Conditional inactivation of the Apc2 allele}

To identify possible orthologs or paralogs of the Apc2 protein, an NCBI-PSI-BLAST search for Apc2 was per- formed. A single mouse Apc2 ortholog (XP_130088.1) and no paralogs were found (Supplemental Fig. 1).

For inactivation of $A p c 2$ in a conditional manner, exons 2-4 of the Apc2 locus were flanked by $\operatorname{lox} P$ sites (floxed allele). Deletion of exons $2-4$ by Cre-mediated recombination leads to a frameshift with stop codons in all three open reading frames. Following transfection with the targeting vector, G418-resistant E14.1 ES cell clones in which one $A p c 2$ allele had been replaced by the targeting construct were identified by Southern blotting. Transient transfection of correctly targeted clones with a plasmid that expressed the Flpc-recombinase created a floxed allele, whereas transfection with a plasmid expressing Cre-recombinase created a deletion allele lacking exons 2-4 ( $\Delta$ allele). Two independent ES cell clones carrying floxed or deletion alleles of $A p c 2$ were injected into $\mathrm{C} 57 \mathrm{Bl} / 6$ blastocysts. Chimeras were crossed with $\mathrm{C} 57 \mathrm{Bl} / 6$ mice to obtain germ-line transmission of either the Apc2 floxed or the Apc2s allele (Fig. 1A-E).

\section{Disruption of Apc2 causes embryonic lethality}

To determine if Apc 2 is essential for mouse development heterozygous $A p c 2^{\Delta /+}$ mice were intercrossed. No homozygous $A p c 2^{\Delta / \Delta}$ mice were born in a total of 120 live births from intercrosses between $A p c 2^{\Delta /+}$ mice. $A p c 2^{\Delta /+}$ mice showed no abnormalities and were born with the expected frequencies (Table 1). Embryos from $A P C 2^{\Delta /+}$ intercrosses were analyzed at E6.5 and E9.5. At E6.5 as well as at E9.5, no homozygous $A p c 2^{\Delta / \Delta}$ embryos were found (Table 1). We conclude that Apc2 is required for early embryogenesis. Mice heterozygous for Apc2 floxed alleles as well as $\Delta$ alleles showed no abnormalities. Homozygous mice carrying Apc2 floxed alleles as well as $A p c 2^{\Delta / f l o x}$ mice had no defects, indicating that the floxed allele of Apc2 is fully functional.

\section{Loss of the APC/C in quiescent hepatocytes causes acute liver failure}

To address APC/C's function in differentiated cells, we investigated the consequences of deleting $A p c 2$ in quiescent hepatocytes of adult livers. We used an $M x$-Cre transgenic line in which Cre can be induced by injection of poly(I) poly(C) (pI/C; Kühn et al. 1995). Six-week-old mice heterozygous for the $\mathrm{Mx}$-Cre transgene and carrying one floxed and one $\Delta$ allele of $A p c 2$ were injected twice with pI/C. Apc2 $2^{\Delta / f l o x}$ and $A p c 2^{\text {flox } /+} M x$-Cre mice were used as controls. Southern and Western blot analysis confirmed that $\mathrm{pI} / \mathrm{C}$ caused efficient deletion of the Apc2 floxed allele (Fig. 2B,C).

Most $A p c 2^{\Delta / f l o x} M x$-Cre mice died during the second week after the first pI/C injection (Fig. 2A). Histological analyses of livers removed shortly before death revealed dramatic changes in six but no difference in four out of $10 \mathrm{Apc} 2^{\Delta / \text { flox }} \mathrm{Mx}$-Cre mice. Hematoxylin/eosin-staining of abnormal livers showed that most hepatocytes were greatly enlarged, lacked nuclear membranes, and con- 
Wirth et al.

A

Figure 1. Generation of a conditional allele for Apc2. (A) Targeting strategy for generating Apc2 floxed and $\Delta$ alleles. Representation of the Apc2 genomic locus, the targeting vector, and the targeted allele. Exons are shown as black boxes. For $A p c 2$, exons 2-4 were flanked by loxP sites (triangles). The selection cassette $\mathrm{NeO}-\mathrm{Tk}$ is indicated as red and green boxes and the DTA cassette as a blue box. The selection cassettes were removed by Flpe-mediated recombination (dashed lines) to obtain floxed alleles, and Cre-mediated recombination was used to generate $\Delta$ alleles. $(B)$ Southern blot analysis to check for integration of the targeting vector at the $A p c 2$ genomic locus. EcoRVrestriction sites for $A p c 2$ and the external probe al were used. $(C)$ Southern blot to determine integration of the third $\operatorname{lox} P$ site by EcoRI-restriction-digest and hybridization with the internal probe b1. (D) Southern blot of targeted ES cells after transient transfection with an Flpe- or Cre-recombinase plasmid to delete the selection cassettes or generate $\Delta$ alleles. Diagnostic sites are EcoRV, and $\mathrm{cl}$ is an internal probe. $(E)$ Southern blot to confirm germ-line transmission of Apc2 flox and $\Delta$ alleles with EcoRV-digested DNA and the internal probe $\mathrm{c} 1$

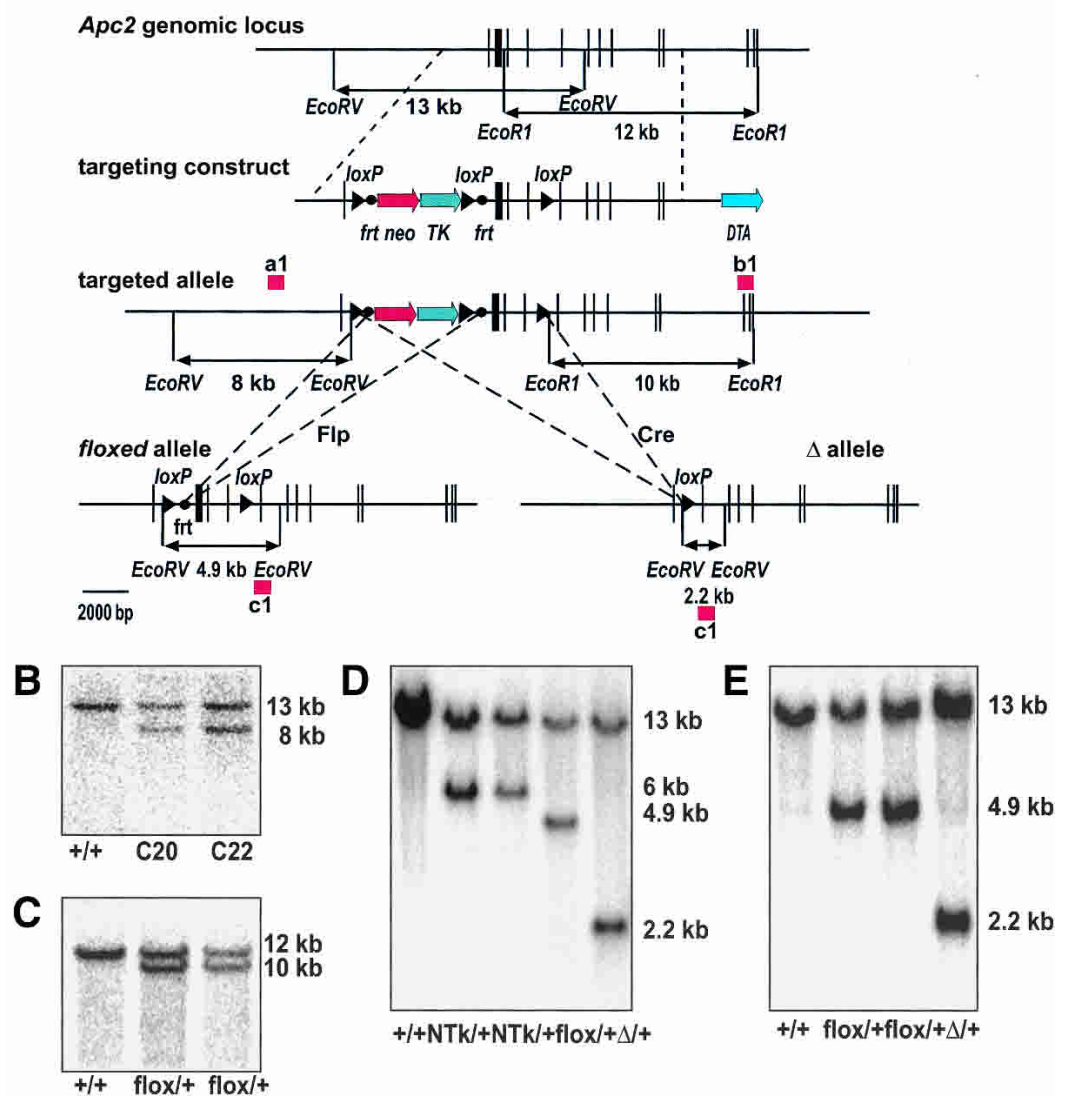

tained condensed chromosomes (Fig. 2E). On squashes from $A p c 2^{\Delta / f l o x} M x-C r e$ livers, $72 \%$ of mitotic hepatocytes were in a prometaphase-like state with condensed chromatin. The shape of individual chromosomes was ill defined (Fig. 2D). Animals with such changes are referred to as affected, whereas animals whose livers showed no changes are referred to as unaffected. Southern blotting demonstrated that there was no correlation between the incidence of liver defects and the efficiency of Apc2 deletion (Fig. 2B; data not shown). PAS staining showed that the abnormal hepatocytes of affected $A p c 2^{\Delta / f l o x} M x-$ Cre mice also lacked glycogen (Fig. 4A below). Levels of the liver enzymes alanine aminotransferase (ALT) and glutamate dehydrogenase (GLDH), as well as the levels of bilirubin, were highly elevated in affected $A p c 2^{\Delta / f l o x}$ $M x$-Cre mice, indicating functional impairment and damage of hepatocytes. These mice died from acute liver

Table 1. Embryonic lethality in $\mathrm{Apc} 2^{\Delta / \Delta}$ mice

\begin{tabular}{lrccc}
\hline$A p c 2^{\Delta /+} \times A p c 2^{\Delta /+}$ & $+/+$ & $+/ \Delta$ & $\Delta / \Delta$ & Total \\
\hline E6.5 & 6 & 16 & 0 & 22 \\
E9.5 & 8 & 22 & 0 & 30 \\
p21 & 39 & 81 & 0 & 120 \\
\hline
\end{tabular}

From intercrosses between $A p c 2^{\Delta /+}$ mice, no $A p c 2^{\Delta / \Delta}$ mice were born. At embryonic days E6.5 and E9.5 all embryos were $A p c 2^{+/+}$or heterozygous for the Apc2s allele. failure. In unaffected $A p c 2^{\Delta / f l o x} M x$-Cre mice as well as in $A p c 2^{\Delta / f l o x}$ mice, ALT, GLDH, and bilirubin were within the normal range (Supplemental Fig. 2).

Rapid and severe bone marrow aplasia in Apc2-deficient mice

Because $\mathrm{Mx}$-Cre-mediated recombination also occurs in hematopoietic cells, we measured hemoglobin levels. The four mice with normal livers all suffered from severe anemia, with hemoglobin levels below $5 \mathrm{~g} / \mathrm{dL}$, which could therefore be the cause of their death. Severe anemia was also observed in two of the mice with abnormal livers. The severe anemia caused by $\mathrm{pI} / \mathrm{C}$ in $A p c 2^{\Delta / f l o x}$ $M x$-Cre mice is caused by deletion of $A p c 2$ in bone marrow cells. To investigate this further, we used FACS analysis (data not shown) and cytospins to analyze hematopoietic cells following $\mathrm{pI} / \mathrm{C}$ injection. Severe bone marrow aplasia usually developed within $4 \mathrm{~d}$ of $\mathrm{pI} / \mathrm{C}$ injection. By day 4, the majority of nucleated cells, including erythroblasts, had disappeared from the bone marrow, which contained mainly erythrocytes and a few lymphocytes (Fig. 3A). On day 3 after $\mathrm{pI} / \mathrm{C}$ injection, we observed an increase in the number of mitotic cells in $A p c 2^{\Delta / f l o x} M x-C r e ~ m i c e ~ c o m p a r e d ~ w i t h ~ t h e ~ A p c 2^{\Delta / f l o x}$ control mice. These findings indicate that abolition of the APC/C from hematopoietic cells leads to metaphase arrest followed by cell death. This process occurred very 
A
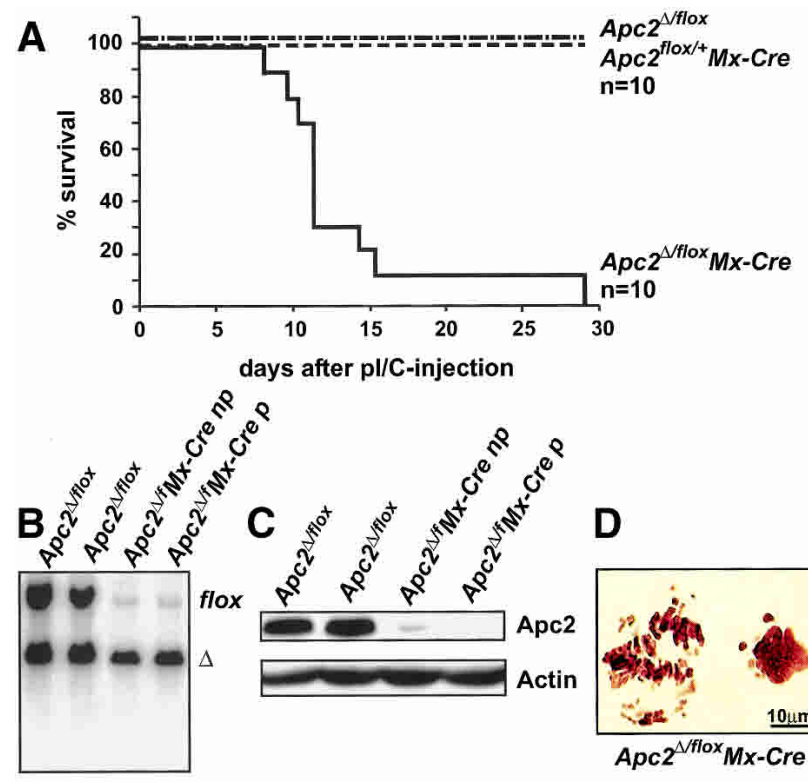

E
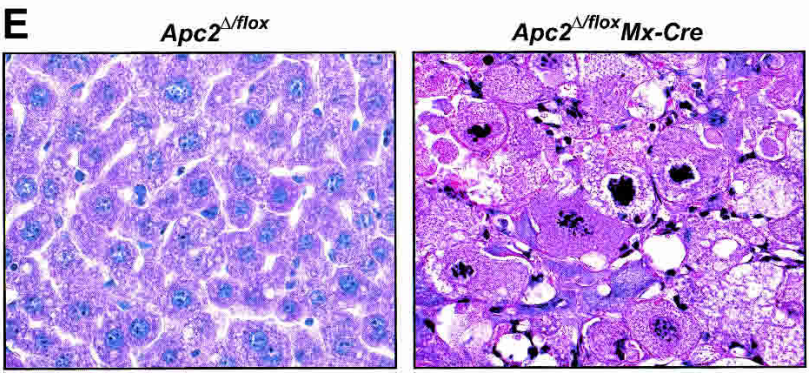

Figure 2. Liver failure in $A p c 2^{\Delta / f l o x} M x$-Cre mice. $(A)$ Survival curve of adult $A p c 2^{\Delta / f l o x} M x-C r e$ and control mice $\left(A p c 2^{\Delta / f l o x}\right.$ and $A p c 2^{\text {flox/+ }} \mathrm{Mx}$-Cre mice) after two injections of $400 \mu \mathrm{g}$ of $\mathrm{pI} / \mathrm{C}$. Most mice died between day 11 and day 14 after the first pI/C injection. (B) Southern blot analysis of $A p c 2^{\Delta / f l o x}$ or $A p c 2^{\Delta / f l o x} M x$-Cre livers; (np) no phenotype, (p) with phenotype. (C) Western blot analysis of $A p c 2^{\Delta / f l o x}$ and $A p c 2^{\Delta / f l o x} M x-C r e$ livers after $\mathrm{pI} / \mathrm{C}$ injection for Apc2-protein levels. Actin is the loading control; (np) no phenotype, (p) phenotype. (D) Squashes from $A p c 2^{\Delta / f l o x} M x$-Cre livers. Seventy-three percent of mitotic cells were in a prometaphase-like state with condensed chromosomes. (E) Hematoxylin/eosin staining of livers from $A p c 2^{\Delta / f l o x}$ and $A p c 2^{\Delta / f l o x} M x-C r e ~ m i c e . ~ A p c 2^{\Delta / f l o x} M x$-Cre hepatocytes appeared larger and had condensed chromosomes.

rapidly so that we never observed a dramatic accumulation of mitotic cells. It is nevertheless unclear whether cell death arising from mitotic arrest can account for the rapid disappearance of bone marrow cells.

\section{Metaphase arrest in unaffected Apc2-deficient hepatocytes after 2/3 hepatectomy}

On Western blot analysis, Apc2 protein levels were reduced in affected as well as in unaffected livers, and no differences in protein levels were observed (Figs. 2C and $5 \mathrm{E}$ below). To address whether any functional Apc2 protein persisted in the hepatocytes of mice whose livers appeared normal after deletion of their $A p c 2$ gene, we investigated the consequences of a $2 / 3$ hepatectomy, which induces cell cycle re-entry. To circumvent lethality due to anemia, $10 \mathrm{Apc2^{ \Delta /flox }} \mathrm{Mx}$-Cre mice and 10 $A p c 2^{\Delta / f l o x}$ mice had bone marrow transplants from Apc2 $2^{+/+}$littermates. Then $2 \times 400 \mu \mathrm{g} /$ mouse pI/C were injected 4 wk posttransplantation, only after ensuring

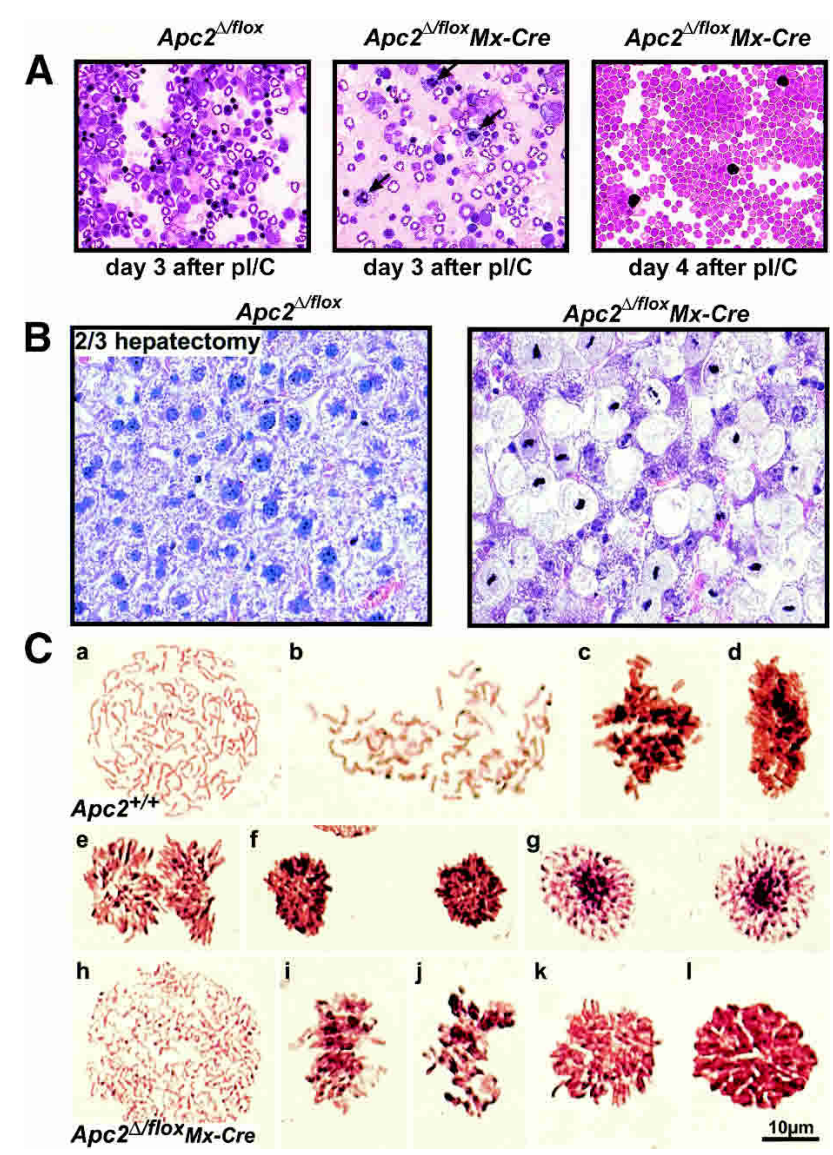

Figure 3. $2 / 3$ hepatectomy in transplanted $A p c 2^{\Delta / f l o x} M x-C r e$ mice causes metaphase arrest. (A) Cytospins of bone marrow cells at day 3 and day 4 after $1 \times 400 \mu \mathrm{g} \mathrm{pI} / \mathrm{C}$ injection. In the $A p c 2^{\Delta / f l o x} M x$-Cre bone marrow, the number of mitotic cells (arrowheads) was increased at day 3 after pI/C. At day 4, only erythrocytes and a few mature lymphocytes could be detected in $A p c 2^{\Delta / f l o x} M x$-Cre bone marrow. (B) Hematoxylin/eosin staining of $A p c 2^{\Delta / f l o x}$ and $A p c 2^{\Delta / f l o x} M x$-Cre livers $72 \mathrm{~h}$ after $2 / 3$ hepatectomy in unaffected $A p c 2^{\Delta / f l o x} M x$-Cre mice. In the Apc2 $2^{\Delta / f l o x} \mathrm{Mx}$-Cre mice, $70 \%$ of the hepatocytes were enlarged and $50 \%$ of the cells were in metaphase. (C) Squashes from $A p c 2^{+/+}$and $A p c 2^{\Delta / f l o x} M x-C r e$ livers $48 \mathrm{~h}$ after $2 / 3$ hepatectomy. $(a-g)$ Mitosis in $A p c 2^{+/+}$hepatocytes. (a) Prophase; $(b)$ early prometaphase, NEB but no biorientation of chromosomes; (c) late prometaphase, not all chromosomes are aligned yet at the equatorial plate; $(d)$ metaphase, sideview, all chromosomes were aligned at the equatorial plate; $(e)$ anaphase, sister chromatids were segregating to opposite poles; $(f)$ telophase; $(g)$ early $\mathrm{G}_{1}$. (h-l) Mitosis in Apc $2^{\Delta / \text { flox }} \mathrm{Mx}$-Cre hepatocytes. (h) Prophase, no difference from $A p c 2^{+/+}$hepatocytes; (i) prometaphase, the shape of individual chromosomes appeared ill defined; (j) prometaphase-like cell with condensed chromatin; $(k)$ metaphase, polar view; (1) metaphase-like cell with condensed chromatin, but individual chromosomes could not be observed. 
Wirth et al.

that blood counts were normal. Three $A p c 2^{\Delta / f l o x} \mathrm{Mx}$-Cre but no $A p c 2^{\Delta / f l o x}$ mice died of liver failure over a period of $8 \mathrm{wk}$ after $\mathrm{pI} / \mathrm{C}$ injection (data not shown). In the seven surviving $A p c 2^{\Delta / f l o x} M x-C r e$ mice, $2 / 3$ hepatectomy caused death within 3-5 d. Histological analyses showed that $70 \%$ of the mitotic hepatocytes of these mice were arrested in metaphase (Fig. 3B), despite appearing normal before the operation (data not shown). Squashes from $A p c 2^{\Delta / f l o x} M x$-Cre livers confirmed that their chromosomes were condensed and frequently aligned in a manner similar to metaphases from $\mathrm{Apc2}^{+/+}$ mice. However, the chromosomes of cells in metaphase lacking Apc2 were overcondensed and the metaphase plates were smaller than in the controls in $95 \%$ of the cells. (Fig. 3C, k and 1). Apc2 $2^{\Delta / f l o x}$ mice survived this regime, and their hepatocytes appeared no different from those of wild-type mice. These findings imply that the Apc2 protein really had been removed from unaffected livers whose $A p c 2$ gene had been deleted. They also demonstrate that the APC/C is essential for the onset of anaphase in mammalian cells.

\section{Analysis of APC/C substrates in Apc2-deficient hepatocytes}

We next characterized the cell cycle state of hepatocytes from livers that were clearly affected merely by deletion of $A p c 2$ in more detail. Very few $A p c 2^{\Delta / f l o x}(<2 \%)$ but $50 \%-70 \%$ of $A p c 2^{\Delta / f l o x} M x-C r e$ hepatocytes were $\mathrm{Ki} 67$ and $\mathrm{pH} 3$ positive (Fig. 4B). In situ immunofluorescence (Fig. 5A-D) showed that a high percentage of the cells were positive for $\mathrm{Ki} 67, \mathrm{pH} 3, \mathrm{Cdc} 20$, and cyclin A2. In mitotic cells, both cyclin A2 and Cdc20 were associated with the spindle as well as distributed throughout the cytoplasm owing to nuclear envelope breakdown (NEB). The affected livers also contained hepatocytes that had not yet entered mitosis but nevertheless contained high levels of cyclin A2 within their nuclei. Western blotting (Fig. 5E) showed that deletion of Apc2 greatly reduced the amount of Apc2 protein in both affected and unaffected livers. Affected but not unaffected livers had high levels of proteins known to be APC/C substrates. The levels of the $\mathrm{G}_{1}$-substrates cyclin D1 and SnoN as well as the mitotic substrates cyclin A2, cyclin B1, securin, Plk, and Cdc20 were comparable to those of mouse embryonic fibroblasts (MEF) treated with nocodazole. The cyclin kinase inhibitor p27 was down-regulated in affected livers. Livers apparently unaffected by deletion of $A p c 2$ had low levels of APC/C targets and high levels of p27. Cyclin E and Cdc6 were expressed in hepatocytes from affected and unaffected $A p c 2^{\Delta / f l o x} M x$-Cre mice as well as from $A p c 2^{\Delta / f l o x}$ mice, and there was no difference in the expression levels (data not shown). These results suggest that deletion of Apc2 by $\mathrm{Mx}$-Cre induces hepatocytes of some but not all livers to enter into a proliferative state, which results in a mitotic arrest. The cell cycle re-entry of hepatocytes from $A p c 2^{\Delta / f l o x} \mathrm{Mx}$-Cre mice cannot be caused by DNA damage induced by extended expression of the Cre recombinase (Loonstra et al. 2001; Silver and Livingston 2001) because pI/C caused no
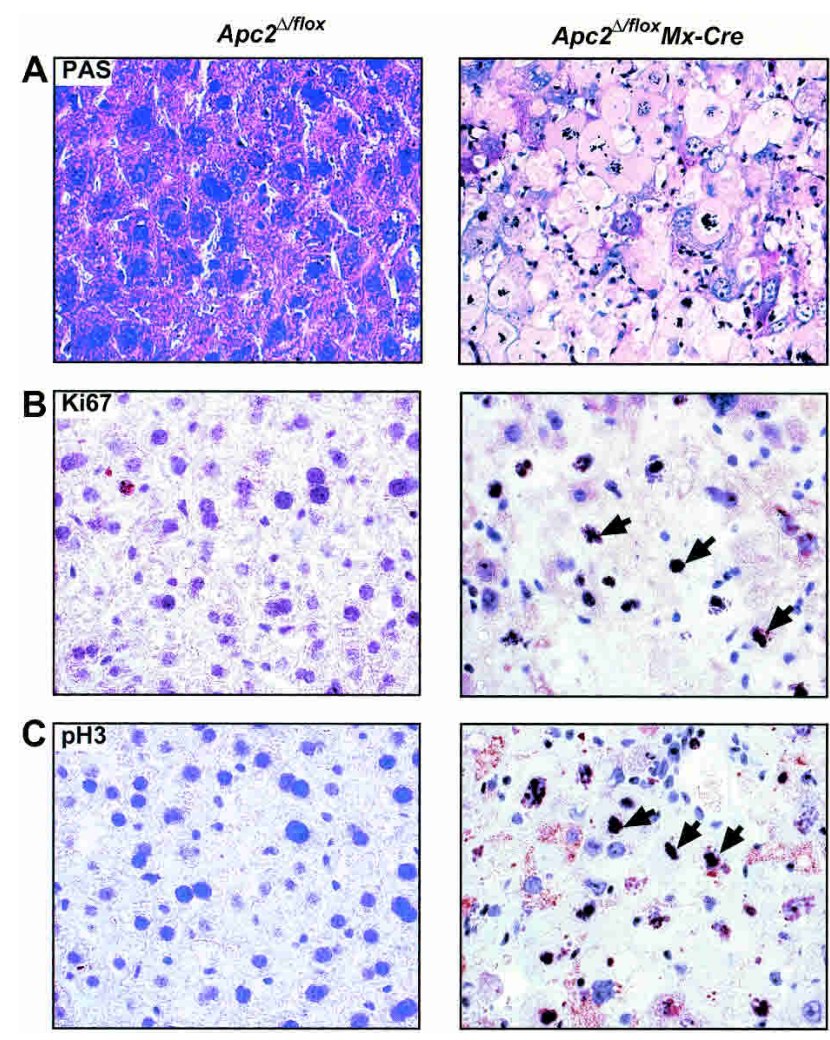

Figure 4. $A p c 2^{\Delta / f l o x} M x$-Cre hepatocytes cannot maintain liver function and arrest in mitosis. (A) PAS staining. Most $A p c 2^{\Delta / f l o x}$ $M x-C r e$ hepatocytes were PAS-negative as indicated by the loss of the staining. $(B) \mathrm{Ki} 67$ and $(C) \mathrm{pH} 3$ staining of $A p c 2^{\Delta / f l o x}$ and $A p c 2^{\Delta / f l o x} M x-C r e$ livers at day 11 after $\mathrm{pI} / \mathrm{C}$ injection. The majority of $A p c 2^{\Delta / f l o x} M x$-Cre hepatocytes were in mitosis. Arrowheads point to $\mathrm{Ki} 67$ - or $\mathrm{pH} 3$-positive cells.

significant increase in the number of Ki67-positive hepatocytes in $\mathrm{Apc} 2^{f l o x /+} \mathrm{Mx}$-Cre mice. Fewer than $3 \%$ of hepatocytes from $\mathrm{Apc2^{flox } / +} \mathrm{Mx}$-Cre or $\mathrm{Apc} 2^{\Delta / f l o x}$ livers were Ki67-positive at day 3, 7, and 28 after $\mathrm{pI} / \mathrm{C}$ injection. (Supplemental Fig. 4).

\section{Deletion of Apc2 in hepatocytes alone causes their proliferation and mitotic arrest}

The finding that deletion of $A p c 2$ by $M x-C r e$ causes hepatocyte proliferation suggests that APC/C activity may be necessary to maintain hepatocytes in a quiescent state. This would be a novel activity for a ubiquitin protein ligase hitherto implicated in promoting anaphase. However, our observation that Apc2 deletion causes anemia as well as liver failure raises the possibility that the proliferation of hepatocytes might be a secondary effect of apoptosis. To address this, we analyzed livers from $A p c 2^{\Delta / f l o x} \mathrm{Mx}$-Cre and $\mathrm{Apc2^{ \Delta /flox }}$ mice at day 0, 1, 2, 3, 4, and 5 after $\mathrm{pI} / \mathrm{C}$ injection by TUNEL assay. In $A p c 2^{\Delta / f l o x}$ $M x-C r e$ mice, anemia occurs within 3-4 d after pI/C injection. Cre-mediated Apc2 deletion caused no increase in TUNEL positive cells (Supplemental Fig. 3A). We did, 


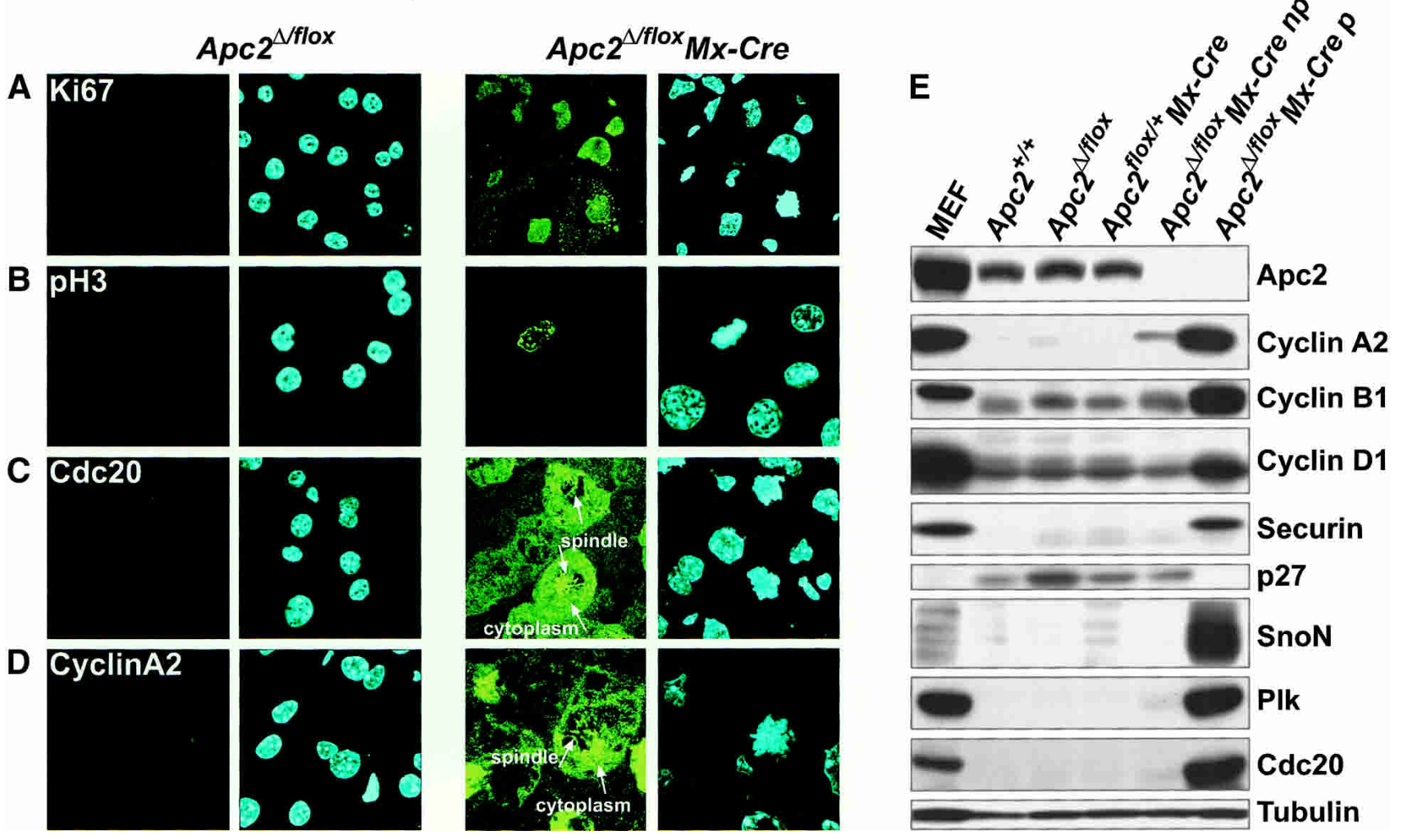

Figure 5. Levels of $\mathrm{APC} / \mathrm{C}$ targets in $A p c 2^{\Delta / f l o x} M x$-Cre hepatocytes. Cryosections of $A p c 2^{\Delta / f l o x}$ and Apc2 $2^{\Delta / f l o x} M x$-Cre livers were analyzed by indirect immunofluorescence. $(A)$ We found that $50 \%-70 \%$ of $A p c 2^{\Delta / f l o x} M x-C r e$ hepatocytes stained for Ki67, indicating that they entered from a quiescent state to a proliferative state. About $1 \%$ of Ki67-positive cells were detected in $A p c 2^{\Delta / f l o x}$ hepatocytes. (B) Apc2 $2^{\Delta / f l o x} \mathrm{Mx}$-Cre hepatocytes with condensed chromosomes were positive for the mitotic marker pH3. A few pH3-positive cells were found in $A p c 2^{\Delta / f l o x}$ livers. $(C)$ The mitotic regulator of the APC/C Cdc20 was expressed in Apc2 $2^{\Delta / f l o x} M x-C r e$ hepatocytes with condensed chromosomes. It localized to the spindle and the cytoplasm after nuclear envelope breakdown (arrowheads). ( $D$ ) Cyclin A2 was found in mitotic $A p c 2^{\Delta / f l o x} M x-C r e$ hepatocytes at the spindle and in the cytoplasm (arrowheads). A low percentage of $A p c 2^{\Delta / f l o x} \mathrm{Mx}$-Cre cells with uncondensed chromosomes as well as $1 \%$ of $A p c 2^{\Delta / f l o x}$ hepatocytes were cyclin A2 positive. (E) Western blot analysis for Apc2, cyclin A2, cyclin B1, cyclin D1, securin, p27, SnoN, Plk, and Cdc20 of liver extracts. As a positive control, mouse embryonic fibroblasts (MEF) were used. These MEFs had been synchronized by double thymidine block and were released into

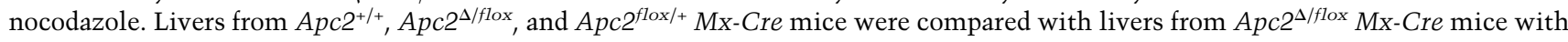
no phenotype (np) and with phenotype (p). Tubulin is the loading control.

however, find $6 \%$ of TUNEL positive cells in affected Apc2 $2^{\Delta / f l o x} \mathrm{Mx}$-Cre livers shortly before death (Supplemental Fig. 3B). These findings are inconsistent with the notion that apoptosis might be a proliferative stimulus in $A p c 2^{\Delta / f l o x} M x$-Cre mice.

To further address whether hypoxia was the cause for re-entry of quiescent hepatocytes into the cell cycle, we investigated the effect of deleting Apc2 solely in hepatocytes using a TTR-Cre transgene. In TTR-Cre transgenic mice, the Cre-recombinase expressed from the transthyretin promoter is flanked by two hormone-binding domains of the murine estrogen receptor. This form of Cre remains inactive until induced by injections of 4-hydroxytamoxifen (4-OHT). Addition of 4-OHT to adult mice carrying the TTR-Cre transgene therefore causes Cre-mediated recombination exclusively in hepatocytes (Tannour-Louet et al. 2002). Southern and Western blots showed that 10 daily 4-OHT injections in $A p c 2^{\text {flox/flox }}$ TTR-Cre mice caused efficient deletion of Apc2 from livers as well as depletion of the Apc2 protein. 4-OHT caused death associated with liver failure (usually within 3 wk of the first injection) in $40 \%$ of $A p c 2^{\text {flox/flox }} T T R$ Cre mice $(n=26)$ but in no $A p c 2^{\text {flox/flox }}$ mice (Fig. 6A). Hepatocytes at the time of death had the same appearance as those produced by deletion of the APC/C by $\mathrm{Mx}$-Cre, namely, they were greatly enlarged and arrested in metaphase (Fig. 6D). Because TTR-Cre does not delete in fibroblasts of Apc2 flox/flox TTR-Cre livers, we observed proliferation of fibroblasts as a response to the increase of hepatocyte cell death (Fig. 6D) and residual bands on Southern and Western blots (Fig. 6B,C). Because no bone marrow aplasia occurred in these mice (data not shown), hypoxia can be excluded as a proliferation stimulus. We conclude that deletion of $A p c 2$ in hepatocytes alone is sufficient to trigger their entry into the cell cycle in $40 \%$ of the mice. In $60 \%$ of Apc2 flox/flox TTR-Cre mice, 4-OHT had no effect despite comparable levels of Apc2 deletion (Fig. 6B,C). Furthermore, the histology of livers of these unaffected mice looked normal (data not shown). 


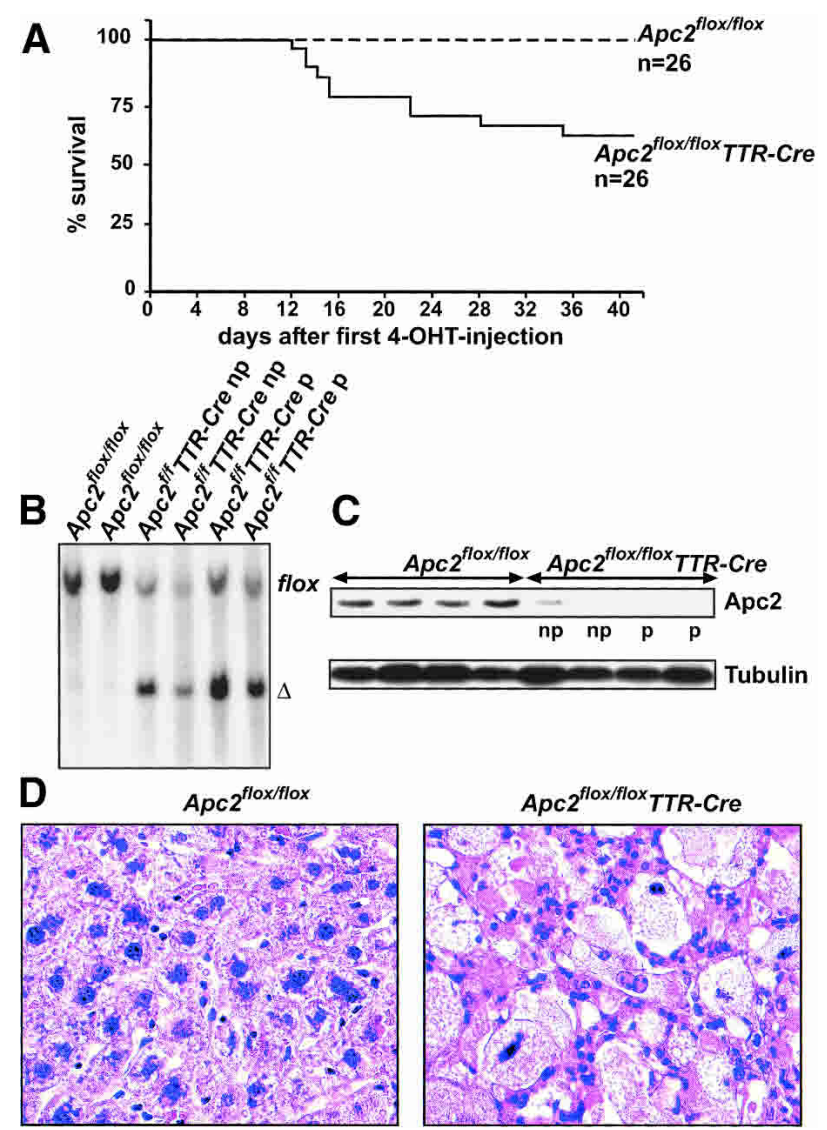

Figure 6. Re-entry of Apc2-deficient hepatocytes into the cell cycle is cell autonomous. (A) Survival curve of $A p c 2^{\text {flox/flox }}$ and Apc2 flox/flox $T T R$-Cre mice. Forty percent of the mice died of liver failure within $14 \mathrm{~d}$ after 4-OHT injections $1 \mathrm{mg} / \mathrm{mouse}$ i.p. five times a week and repetition of injections every other week. (B) Southern blot analysis showing deletion of the floxed allele by TTR-Cre upon injection of 4-OHT. (C) On Western blot analysis, the Apc2 protein levels were down-regulated; (np) no phenotype, (p) phenotype. $(D)$ Histological analysis of $A p c 2^{\text {flox/flox }}$ and affected $A p c 2^{\text {flox/flox }}$ TTR-Cre livers by hematoxylin/eosin staining.

A low proliferation stimulus is sufficient to induce re-entry into the cell cycle in unaffected Apc2-deficient hepatocytes

The finding that $A p c 2$ deletion frequently causes resting hepatocytes to enter the cell cycle suggests that the $\mathrm{APC} / \mathrm{C}$ has a key role in restricting cell cycle entry. However, in half of the Apc2-deficient mice, hepatocytes remain quiescent. One explanation for this phenotypic variation is that abolition of APC/C lowers the "threshold" for cell cycle entry. In some mice, endogenous mitogenic signals are now capable of triggering cell cycle entry, but in others they are not.

This idea predicts that asymptomatic Apc2-deficient hepatocytes should be more readily stimulated to enter the cell cycle by mitogenic signals that normally would not exceed the threshold needed to promote proliferation. We therefore compared the reaction of $A p c 2^{\text {flox/flox }}$ and asymptomatic Apc2 $2^{\text {flox/flox }}$ TTR-Cre livers to $1 / 4$ hepatectomy. One month after the first 4-OHT-injection, surviving mice were subjected to $1 / 4$ hepatectomy. Mice with histologically abnormal livers were also excluded at this stage. All mice with apparently normal but Apc2-deficient livers died from liver failure between 12 and $15 \mathrm{~d}$ after the $1 / 4$ hepatectomy, whereas the controls survived (Fig. 7A). Histological analysis showed that a large fraction of their hepatocytes were in a mitotic state (data not shown). To compare more directly wild-type and Apc2-deficient mice, we measured the fraction of Ki67-positive hepatocytes 24, 48, and $72 \mathrm{~h}$ after hepatectomy. To measure DNA replication, BrdU was injected every $24 \mathrm{~h}$. There was an increase in Ki67- and BrdUpositive cells by $48 \mathrm{~h}$ in Apc2-deficient mice but none in controls (Fig. $7 \mathrm{~B}, \mathrm{C}$ ). These data imply that $1 / 4$ hepatectomy provokes Apc2-deficient but not $A p c 2^{\text {flox/flox }}$ hepatocytes to enter the cell cycle. Sham operation (surgery without removal of parts of the liver, $n=2$ ) does not cause re-entry into cell cycle of $A p c 2^{\text {flox/flox }}$ TTR-Cre hepatocytes. We conclude that abolition of the APC/C renders all hepatocytes more readily stimulated by mitogenic signals, which sometimes causes them to enter the cell cycle without any obvious external stimulus.

\section{A}

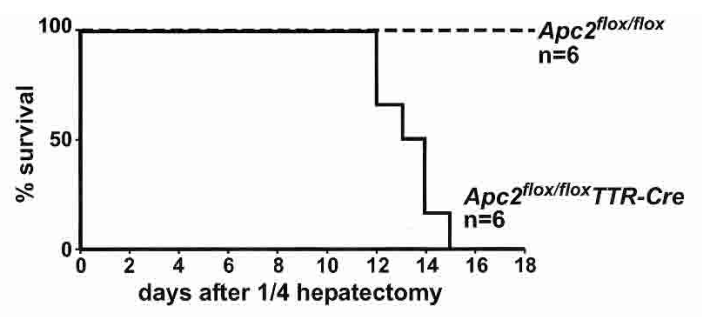

\section{B}
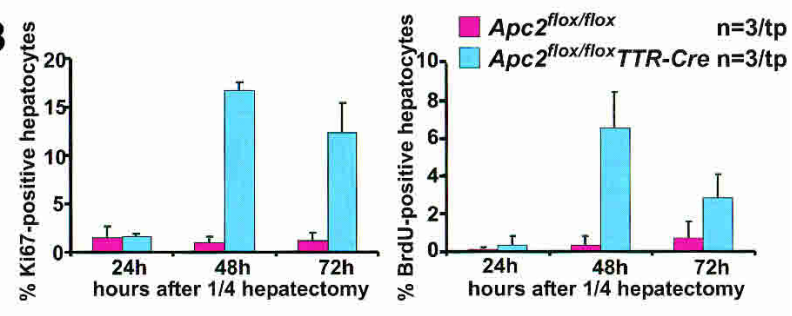

C
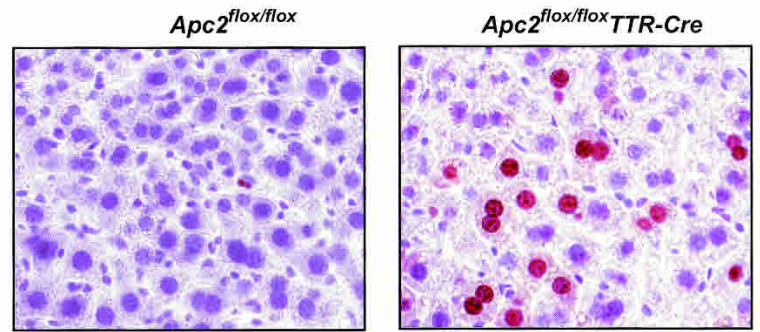

Figure 7. 1/4 hepatectomy induces re-entry into the cell cycle in unaffected $A p c 2^{\text {flox/flox }}$ TTR-Cre livers. (A) Survival curve of $A p c 2^{\text {flox/flox }}$ and $A p c 2^{\text {flox/flox }}$ TTR-Cre mice after $1 / 4$ hepatectomy. Apc $2^{\text {flox/flox }}$ TTR-Cre mice died within the second week after $1 / 4$ hepatectomy of liver failure. $(B)$ Quantification of Ki67- and BrdU-positive cells $24 \mathrm{~h}, 48 \mathrm{~h}$, and $72 \mathrm{~h}$ after $1 / 4$ hepatectomy. For each time point, three $A p c 2^{\text {flox } / \text { flox }}$ and three Apc2 $2^{\text {flox/flox }}$ TTR-Cre mice were used. (C) Ki67 staining $48 \mathrm{~h}$ after $1 / 4$ hepatectomy. 


\section{Discussion}

In addition to its key regulatory function during cell proliferation, the APC/C is known to be also active in postmitotic differentiated cells (Gieffers et al. 1999). However, the significance of this activity is not understood. To investigate the role of the APC/C in quiescent cells, we conditionally deleted one of its subunits, Apc2, in hepatocytes in vivo.

\section{The mammalian APC/C is needed for anaphase}

Genetic studies have implicated the APC/C in triggering anaphase in a wide variety of eukaryotic organisms. $\mathrm{Mu}-$ tations that affect the APC/C or its activator Cdc20 cause yeast (Irniger et al. 1995), fly (Sigrist and Lehner 1997), and worm (Furuta et al. 2000; Golden et al. 2000) cells to arrest in a metaphase-like state with unseparated sister chromatids. Injection of antibodies specific for CDC16/APC6 and CDC27/APC3 produce a similar phenotype in mammalian tissue culture cells (Tugendreich et al. 1995). Nevertheless, antibody injection experiments are difficult to interpret, and the effects of inactivating the APC/C in mammalian cells has never been investigated using genetics. Because the consequences of inactivating genes in the mouse have often proven different from that expected from tissue culture experiments, it was important to establish whether the APC/C is essential for mitosis in living animals.

Our inability to detect $A p c 2^{\Delta / \Delta}$ E6.5 embryos arising from crosses between $A p c 2^{\Delta /+}$ mice implies that the $\mathrm{APC} / \mathrm{C}$ is essential for embryonic development. This is consistent with the finding that inactivation of the APC/C subunit Apc10 in mice is early embryonic lethal (Pravtcheva and Wise 1996). Using the Mx-Cre system, we managed to delete $A p c 2$ in resting hepatocytes. 2/3 hepatectomy caused these Apc2-deficient although otherwise apparently normal quiescent cells to embark on proliferation. Our finding that the majority of these cells arrested in a metaphase-like state 3 to $5 \mathrm{~d}$ after 2/3 hepatectomy demonstrates that the APC/C is necessary for anaphase in mammals in vivo.

\section{Loss of the APC/C in hepatocytes leads to cell cycle re-entry}

Abolition of the APC/C has also dramatic consequences in quiescent hepatocytes. Within 2 wk of Apc2 deletion caused by $\mathrm{pI} / \mathrm{C}$ stimulation of an $\mathrm{Mx}$-Cre transgene, most mice died. In some cases, this appears to have been caused by severe anemia due to loss of APC/C in the bone marrow. In most cases, however, death appears to be caused by liver failure brought about by the arrest of hepatocytes in a mitotic state during which normal liver function cannot be maintained. Crucially, deletion of Apc2 solely in hepatocytes (using a 4-hydroxytamoxifeninducible TTR-Cre transgene) produces a similar phenotype, which cannot therefore be a secondary consequence of bone marrow failure. It is still unclear whether the massive changes brought about by deletion of Apc2 in the bone marrow are caused by apoptosis arising from mitotic arrest or by some more direct effect on cell survival.
The liver pathology is caused by the spontaneous entry of a large number of hepatocytes into the cell cycle, which in the absence of APC/C causes their arrest in a mitotic-like state. Several known substrates of the APC/C such as mitotic cyclins, securin, and SnoN accumulate to high levels in these cells, whereas other $S$ phase-promoting proteins like Cdc6 and cyclin E are expressed at the same level as in wild-type hepatocytes. This finding implies that the APC/C has a crucial role in quiescent hepatocytes, namely, to restrain their re-entry into the cell cycle. The APC/C could perform this function either by suppressing the production of extracellular mitogens or more directly by suppressing accumulation of intracellular proteins capable of promoting proliferative growth.

Surprisingly, deletion of $A p c 2$ fails to cause a proliferative response in about half of all mice. Despite the disappearance of Apc2 protein, the hepatocytes of such mice remain in a quiescent state that appears very similar to that of wild-type. These asymptomatic Apc2-deficient hepatocytes are nevertheless in an altered state because they are more readily stimulated to embark on DNA replication than wild-type. Within 48 h, 1/4 hepatectomy caused many Apc2-deficient hepatocytes to become Ki67 positive and to enter S phase. We conclude that abolition of the APC/C causes a major change in the state of quiescent hepatocytes such that they are more readily stimulated to embark on cell proliferation. Their readiness to enter the cell cycle allows them to do so either spontaneously or in response to mitogenic signals. Necrosis or apoptosis can be excluded as a stimulus for re-entry into the cell cycle because depletion of the APC/C also caused hepatocytes of livers apparently unaffected by $A p c 2$ deletion to enter the cell cycle upon 1/4 hepatectomy. A failure to destroy SnoN seems unlikely to be responsible because SnoN levels, although clearly elevated in APC/C-deficient cells that have arrested in a mitotic state, are not significantly increased in asymptomatic APC/C-deficient livers. We also found no obvious changes in the levels of other APC/C substrates such as cyclin B1, securin, Plk, and Cdc20, and only a very small if any increase in the level of cyclin A2.

Although no other study has directly addressed the $\mathrm{APC} / \mathrm{C}^{\prime}$ s role in quiescent cells, our finding that abolition of the APC/C promotes cell cycle entry is consistent with the finding that Drosophila embryos lacking fizzyrelated (Cdh1) progress through an extra cell cycle (Sigrist and Lehner 1997) and with the finding that chicken tissue culture cells lacking a particular Cdh1 gene are less likely to be arrested in $\mathrm{G}_{1}$ by rapamycin (Sudo et al. 2001). Both these and our data all point to a key role for the APC/C in suppressing proliferation as well as promoting anaphase during mitosis.

\section{Materials and methods}

NCBI-PSI-BLAST search for Apc2

Proteins from Homo sapiens, Mus musculus, Drosophila melanogaster, Caenorhabditis elegans, Schizosaccharomyces 
pombe, Saccharomyces cerevisiae, and Arabidopsis thaliana were selected by an NCBI-PSI-BLAST search (Schaffer et al. 2001) with full-length $S$. cerevisiae Apc2 in the $\mathrm{nr}$ database (e-value threshold for inclusion in the model: 0.005, 10 rounds) and sorted by taxonomy with the taxonomy workbench (Wildpaner et al. 2001). Each species set was filtered for $90 \%$ identity with cd-hit ( $\mathrm{Li}$ et al. 2001), and the remaining proteins were aligned with T-Coffee (Notredame et al. 2000). A phylogenetic tree was created with PHYLO_WIN (Galtier et al. 1996).

\section{Generation of $\mathrm{Apc} 2^{\text {flox }}$ and $\mathrm{Apc} 2^{\Delta}$ mice}

Mouse Apc2 genomic DNA was isolated from a 129/Sv BAC library (Research Genetics) by using a cDNA probe derived from dbEST W13204. BAC clone 396K23 was used for construction of the $A p c 2$ targeting vector. A polylinker containing one $l_{0 x P}$ site was inserted into the BSSHII site of pBluescript II KS(-) (Stratagene). For positive and negative selection, a floxed and frted pKNeo-HSVTk cassette was inserted. MCI DTA was used to select against random integration. For the targeting construct, 1.5-kb NotI and 6-kb NdeI fragments were used as short and long regions of homology. A $2-\mathrm{kb}$ Xhol fragment contained the floxed sequence of exons 2-4.

Gene targeting was performed in E14.1 ES cells by electroporating $15 \mu \mathrm{g}$ of AscI-linearized targeting construct. For selection, $300 \mu \mathrm{g} / \mathrm{mL}$ G418 was used, and clones were screened by Southern blot analysis of EcoRV-digested ES cell DNA by using an $\sim 350$-bp external probe. The targeting frequency for correct integration of the targeting vector at the Apc2 genomic locus was $1 / 58$. The presence of the second $\operatorname{lox} P$ site was confirmed by using an EcoRI digest and a second C-terminal external probe. Positive clones were electroporated with $25 \mu \mathrm{g}$ of pCAGGSFlpeIRESpuro (F. Stewart) or $25 \mu \mathrm{g}$ of pMC-Cre $(\mathrm{H}$. $\mathrm{Gu})$, and negative selection with $2 \mu \mathrm{M}$ Gancyclovir was used. Clones were screened for loss of selection cassette (Flpe) or deletion of selection cassette and floxed part (Cre) to generate a $\Delta$ allele by Southern blot analysis of an EcoRV digest with an internal probe. Apc2 floxed alleles were obtained with a frequency of $1 / 8$ and $\Delta$ alleles with a frequency of $1 / 24$. Chimeric mice were created by injection of two independent targeted ES cell clones into $\mathrm{C} 57 \mathrm{Bl} / 6$ blastocysts. Chimeric mice were crossed to $\mathrm{C} 57 \mathrm{Bl} / 6$ wild-type animals and maintained on a mixed genetic background of C57Bl/6 and 129/Sv.

\section{BAC library high-density filter hybridization and Southern blot analysis}

BAC library high-density filters were prehybridized in $1 \mathrm{mM}$ EDTA/0.5 M NaPi (pH 7.2), 7\% SDS for $1 \mathrm{~h}$. Then $50 \mathrm{ng}$ of ${ }^{32} \mathrm{P}$-labeled probe for $4-5$ filters was added and hybridized overnight at $65^{\circ} \mathrm{C}$. Filters were washed twice in $40 \mathrm{mM} \mathrm{NaPi} / \mathrm{pH}$ $7.2) / 1 \%$ SDS and exposed overnight.

For Southern blot analysis, cells or tissue was incubated in 50 $\mathrm{mM}$ Tris- $\mathrm{HCl}(\mathrm{pH} 8), 100 \mathrm{mM} \mathrm{NaCl}, 1 \%$ SDS, and $0.5 \mathrm{mg} / \mathrm{mL}$ Proteinase K overnight. Fragments were separated on a $0.5 \%$ Agarose gel, depurinated with $0.25 \mathrm{~N} \mathrm{HCl}$ for $10 \mathrm{~min}$, denatured in $0.2 \mathrm{~N} \mathrm{NaOH} / 0.6 \mathrm{M} \mathrm{NaCl}$ for $30 \mathrm{~min}$, and neutralized in 0.5 $\mathrm{M}$ Tris- $\mathrm{HCl}(\mathrm{pH} 7.5) / 1.5 \mathrm{M} \mathrm{NaCl}$. After transfer to a nylon membrane and prehybridization, the blot was hybridized in $1 \mathrm{mM}$ EDTA/0.5 M NaPi (pH 7.2)/7\% SDS with $25 \mathrm{ng}$ of ${ }^{32} \mathrm{P}$-labeled probe overnight, washed twice in $40 \mathrm{mM} \mathrm{NaPi}(\mathrm{pH} 7.2) / 1 \%$ SDS, and exposed.

\section{Western blot analysis}

Homogenization of tissues was performed in extraction buffer (1:1 Tween 20:NP-40 buffer. Tween 20 buffer: 50 mM HEPES at
pH 7.5, $150 \mathrm{mM} \mathrm{NaCl}, 10 \mathrm{mM}$ EDTA, 0.2\% Tween 20. NP-40 buffer: $1 \% \mathrm{NP}-40,50 \mathrm{mM}$ Tris- $\mathrm{HCl}$ at $\mathrm{pH} 7.5,150 \mathrm{mM} \mathrm{NaCl}, 10$ mM EDTA), supplemented with phosphatase and protease inhibitors. Then $100 \mu \mathrm{g}$ protein per lane was loaded on a $8 \%$ and $13 \%$ gel and transferred to a PVDF membrane (Millipore). For detection of proteins antibodies against cyclin B1 (1:1000; Upstate Biotechnology), cyclin A2 (1:1000; gift from Mark Carrington, University of Cambridge, Cambridge, UK), Apc2 and Cdc20 (1:1000; gifts from Christian Gieffers, Affiris, Wien, Austria, and Edgar Kramer, MPI of Neurobiology, Martinsried, Germany), SnoN (5 $\mu \mathrm{g} / \mathrm{mL}$; Cascade Bioscience), cyclin D1, Plk (1:250; Zymed), and p27 (1:100; Santa Cruz), actin (1:100; Sigma), and tubulin (1:1000; Sigma) were used.

\section{Immunofluorescence}

Tissues were frozen in liquid nitrogen and embedded in OCT tissue TEC. Then 10- $\mu \mathrm{m}$ cryosections were cut and fixed in $4 \%$ paraformaldehyde for $20 \mathrm{~min}$. Sections were incubated in 50 $\mathrm{mM} \mathrm{NH}_{4} / \mathrm{Cl}$ in PBS and $0.1 \%$ Triton-X for $3 \mathrm{~min}$. Unspecific binding was blocked with $3 \%$ BSA in PBST for $1 \mathrm{~h}$. For dilution of primary and secondary antibody, blocking solution was used and sections were incubated for $1 \mathrm{~h}$. After three washes in PBST, slides were stained with $1 \mu \mathrm{g} / \mathrm{mL}$ DAPI and mounted (Vectashield H-1000; Vector Laboratories). For Apc2 staining, tissues were fixed in $4 \%$ paraformaldehyde for $20 \mathrm{~min}$ and incubated in $0.25 \%$ Triton-X for $10 \mathrm{~min}$. Primary antibodies against cyclin A2 (gift from Mark Carrington) and Cdc20 (gift from Edgar Kramer) were used in a concentration of 1:50. For antibodies against tubulin (Sigma), pH3 (Upstate Biotechnology), and Ki67 (Novocastra Laboratories), the concentration was 1:1000 and against Apc2 1:250 (gift from Christian Gieffers). Secondary antibodies were anti-mouse- (1:1000) or anti-rabbit-Alexa 488 1:400 (Molecular Probes).

\section{Immunohistochemistry and TUNEL assay}

Tissues were fixed in $4 \%$ paraformaldehyde overnight, dehydrated, and embedded in paraffin. Then 5 - $\mu$ m paraffin sections were cut, rehydrated, and boiled in $10 \mathrm{mM} \mathrm{NaCitrat}(\mathrm{pH}$ 6) for $13 \mathrm{~min}$. Unspecific binding was reduced by incubation in $0.5 \%$ $\mathrm{H}_{2} \mathrm{O}_{2}$ for 15 min. After blocking in 3\% BSA/PBS, sections were stained with anti-Ki67 (1:1000; Novocastra Laboratories) or anti-pH3-antibody (1:1000; Upstate Biotechnology) overnight. Secondary antibody incubation and enzymatic reaction were performed by using the $\mathrm{ABC}$ and $\mathrm{DAB}$ staining kit (Vector Laboratories). Sections were counterstained with hematoxylin for 3 $\min$.

For the detection of apoptotic cells the In Situ Cell Death Detection Kit (Roche) was used on $0.1 \%$ NaCitrat and $0.1 \%$ Triton-X pretreated cryosections.

\section{Cytospins}

For cytospins, $5 \times 10^{5}$ cells/well were centrifuged on a slide at $700 \mathrm{rpm}$ for $7 \mathrm{~min}$. Cells were stained with Quick stain (Merck).

\section{Squashing procedure}

Livers were cut into small $\left(1-3 \mathrm{~mm}^{3}\right)$ pieces and immediately fixed in freshly prepared Carnoy's (methanol:acetic acid). After five changes of fixative, the material was stored at $-20^{\circ} \mathrm{C}$. For cytological preparations, small pieces were put on a slide, and several drops of $50 \%$ acetic acid in water were added to soften the tissue. When the tissue lost its whitish color $(-30 \mathrm{sec})$, most of the liquid was removed using filter paper. Next, three 
drops of lactopropionic orcein (2\% of orcein-Gurr in 1:1 lactic acid:propionic acid) was added for 2-3 min. A coverslip was placed on top, and the material was gently dispersed by smoothly moving the coverslip with the tip of a pencil. After 1 $\mathrm{h}$ of staining, one corner of the coverslip was held with a filter paper to avoid movement and a spiral was drawn on the coverslip with the pencil starting from the center of the material to the edges. A piece of filter paper was put onto the coverslip, and the material was strongly squashed.

\section{BrdU staining}

For BrdU staining, $50 \mu \mathrm{g} / \mathrm{g}$ BrdU was injected with the anesthesia for $2 / 3$ hepatectomy i.p. and repeated every $24 \mathrm{~h}$. Livers were fixed in $4 \%$ paraformaldehyde overnight and dehydrated. After embedding into paraffin, $6-\mu \mathrm{m}$ sections were cut. After rehydration, sections were incubated in $2 \mathrm{~N} \mathrm{HCl}$ for $45 \mathrm{~min}, 1 \times$ Trypsin for $45 \mathrm{~min}$, and $0.5 \% \mathrm{H}_{2} \mathrm{O}_{2}$ for $30 \mathrm{~min}$. Unspecific binding was blocked by incubation in 3\% BSA in PBS, and sections were incubated with anti-BrdU-antibody (1:100; Zymed) overnight. The enzymatic reaction was performed by using the $\mathrm{ABC}$ and $\mathrm{DAB}$ staining kit (Vector Laboratories). Sections were counterstained with hematoxylin for $3 \mathrm{~min}$.

\section{Induction of Cre in vivo}

For expression of Mx-Cre, $400 \mu \mathrm{g}(1 \mathrm{mg} / \mathrm{mL})$ of $\mathrm{pI} / \mathrm{C}$ (Pharmacia) i.p. was injected twice with an interval of $72 \mathrm{~h}$. For deletion in hematopoietic cells, $1 \times 400 \mu \mathrm{g}$ of $\mathrm{pI} / \mathrm{C}$ i.p. was used.

4-OHT injections were performed as described in Indra et al. (1999). 4-OHT (Sigma) was diluted in $100 \% \mathrm{EtOH}$ to obtain a 10 $\mathrm{mg} / 100 \mu \mathrm{L}$ solution. For the preparation of a $10 \mathrm{mg} / \mathrm{mL} 4-\mathrm{OHT}$ solution, sunflower oil was added. After sonication for $30 \mathrm{~min}$ with a Kantes sonicator, $1 \mathrm{mg} / 100 \mu \mathrm{L}$ 4-OHT solution per mouse was injected i.p. on five consecutive days. Injections were repeated in weeks 3,5 , and 7.

\section{Bone marrow transplantation}

$A p c 2^{\Delta / f l o x} M x-C r e$ and $A p c 2^{\Delta / f l o x}$ mice were irradiated with $1100 \mathrm{rad}$. Then, $24 \mathrm{~h}$ after irradiation, $4 \times 10^{6}$ bone marrow cells from $\mathrm{Apc2}^{+/+}$donor littermates were injected i.v. Successful bone marrow reconstitution was evaluated 4 wk after transplantation by blood checks. A total of $2 \times 400 \mu \mathrm{g} /$ mouse pI/C i.p. with an interval of $72 \mathrm{~h}$ was injected.

\section{2/3 and 1/4 hepatectomy}

Mice were anaesthetized with $13 \mu \mathrm{L} / \mathrm{g} 2.5 \%$ Avertin i.p., and an abdominal transversal incision below the xyphoid process was performed. For $2 / 3$ hepatectomies, the large left and the two median lobes were ligated and removed. For $1 / 4$ hepatectomies, the left lobe was taken out. In Sham-operated animals, the large left and the two median lobes were exposed and put back without any removal of tissue.

\section{Acknowledgments}

We thank Hartmut Beug, Meinrad Busslinger, Jan-Michael Peters, Erwin Wagner, and their groups for providing advice and reagents. Special thanks go to Dónal O'Carroll for the introduction to ES cell work and Hans Christian Theussl for blastocyst injections. Christian Gieffers, Edgar Kramer, and Mark Carrington provided antibodies, and Francis Stewart the Flpe-plasmid.
We received Cre-transgenic mice from Wolfgang Wurst with permission from Ralf Kühn, Jamey Marth, Mireille VasseurCognet, and the Busslinger and Wagner group. We thank Nicole Firnberg for isolation of embryos at E6.5 and Grzegorz Sumara for help with hepatectomies. Alexander Schleiffer performed the bioinformatics searches. We appreciate the critical reading and discussion of the manuscript by Hartmut Beug and JanMichael Peters. The IMP is funded by Boehringer Ingelheim, and this work was partly supported by a network grant from the European Community for K.N. (contact number: QLG1-CT2001-02026, shared costs action U2P2), a Marie Curie fellowship from the European Community for R.R., and a Research Fellowship from the German Research Foundation (Deutsche Forschungsgemeinschaft, DFG) for K.G.W.

The publication costs of this article were defrayed in part by payment of page charges. This article must therefore be hereby marked "advertisement" in accordance with 18 USC section 1734 solely to indicate this fact.

\section{References}

Amon, A., Irniger, S., and Nasmyth, K. 1994. Closing the cell cycle circle in yeast: $\mathrm{G}_{2}$ cyclin proteolysis initiated at mitosis persists until the activation of $\mathrm{G}_{1}$ cyclins in the next cycle. Cell 77: 1037-1050.

Ben-Neriah, Y. 2002. Regulatory functions of ubiquitination in the immune system. Nat. Immunol. 3: 20-26.

Brandeis, M. and Hunt, T. 1996. The proteolysis of mitotic cyclins in mammalian cells persists from the end of mitosis until the onset of S phase. EMBO J. 15: 5280-5289.

Conaway, R.C., Brower, C.S., and Conaway, J.W. 2002. Emerging roles of ubiquitin in transcription regulation. Science 296: $1254-1258$.

Furuta, T., Tuck, S., Kirchner, J., Koch, B., Auty, R., Kitagawa, R., Rose, A.M., and Greenstein, D. 2000. EMB-30: An APC4 homologue required for metaphase-to-anaphase transitions during meiosis and mitosis in Caenorhabditis elegans. Mol. Biol. Cell 11: 1401-1419.

Galtier, N., Gouy, M., and Gautier, C. 1996. SEAVIEW and PHYLO_WIN: Two graphic tools for sequence alignment and molecular phylogeny. Comput. Appl. Biosci. 12: 543 548.

Gieffers, C., Peters, B.H., Kramer, E.R., Dotti, C.G., and Peters, J.M. 1999. Expression of the CDH1-associated form of the anaphase-promoting complex in postmitotic neurons. Proc. Natl. Acad. Sci. 96: 11317-11322.

Gmachl, M., Gieffers, C., Podtelejnikov, A.V., Mann, M., and Peters, J.M. 2000. The RING-H2 finger protein APC11 and the E2 enzyme UBC4 are sufficient to ubiquitinate substrates of the anaphase-promoting complex. Proc. Natl. Acad. Sci. 97: 8973-8978.

Golden, A., Sadler, P.L., Wallenfang, M.R., Schumacher, J.M., Hamill, D.R., Bates, G., Bowerman, B., Seydoux, G., and Shakes, D.C. 2000. Metaphase to anaphase (mat) transitiondefective mutants in Caenorhabditis elegans. J. Cell Biol. 151: 1469-1482.

Harper, J.W., Burton, J.L., and Solomon, M.J. 2002. The anaphase-promoting complex: It's not just for mitosis any more. Genes \& Dev. 16: 2179-2206.

Hilioti, Z., Chung, Y.S., Mochizuki, Y., Hardy, C.F., and CohenFix, O. 2001. The anaphase inhibitor Pds1 binds to the APC/ $\mathrm{C}$-associated protein $\mathrm{Cdc} 20$ in a destruction box-dependent manner. Curr. Biol. 11: 1347-1352.

Indra, A.K., Warot, X., Brocard, J., Bornert, J.M., Xiao, J.H., Chambon, P., and Metzger, D. 1999. Temporally controlled 
site-specific mutagenesis in the basal layer of the epidermis: Comparison of the recombinase activity of the tamoxifeninducible CRE-ER(T) and CRE-ER(T2) recombinases. Nucleic Acids Res. 27: 4324-4327.

Irniger, S. and Nasmyth, K. 1997. The anaphase-promoting complex is required in $G_{1}$ arrested yeast cells to inhibit B-type cyclin accumulation and to prevent uncontrolled entry into S-phase. J. Cell Sci. 110: 1523-1531.

Irniger, S., Piatti, S., Michaelis, C., and Nasmyth, K. 1995. Genes involved in sister chromatid separation are needed for B-type cyclin proteolysis in budding yeast. Cell 81: 269-278.

Jackson, P.K., Eldridge, A.G., Freed, E., Furstenthal, L., Hsu, J.Y., Kaiser, B.K., and Reimann, J.D. 2000. The lore of the RINGs: Substrate recognition and catalysis by ubiquitin ligases. Trends Cell Biol. 10: 429-439.

King, R.W., Peters, J.M., Tugendreich, S., Rolfe, M., Hieter, P., and Kirschner, M.W. 1995. A 20S complex containing CDC27 and CDC16 catalyzes the mitosis-specific conjugation of ubiquitin to cyclin B. Cell 81: 279-288.

Kominami, K., Seth-Smith, H., and Toda, T. 1998. Apc10 and Ste9/Srw1, two regulators of the APC-cyclosome, as well as the CDK inhibitor Rum 1 are required for $\mathrm{G}_{1}$ cell-cycle arrest in fission yeast. EMBO J. 17: 5388-5399.

Kühn, R., Schwenk, F., Aguet, M., and Rajewsky, K. 1995. Inducible gene targeting in mice. Science 269: 1427-1429.

Leverson, J.D., Joazeiro, C.A., Page, A.M., Huang, H., Hieter, P., and Hunter, T. 2000. The APC11 RING-H2 finger mediates E2-dependent ubiquitination. Mol. Biol. Cell 11: 2315-2325.

Li, W., Jaroszewski, L., and Godzik, A. 2001. Clustering of highly homologous sequences to reduce the size of large protein databases. Bioinformatics 17: 282-283.

Loonstra, A., Vooijs, M., Beverloo, H.B., Allak, B.A., van Drunen, E., Kanaar, R., Berns, A., and Jonkers, J. 2001. Growth inhibition and DNA damage induced by Cre recombinase in mammalian cells. Proc. Nat1. Acad. Sci. 98: 92099214.

Notredame, C., Higgins, D.G., and Heringa, J. 2000. T-Coffee: A novel method for fast and accurate multiple sequence alignment. J. Mol. Biol. 302: 205-217.

Peters, J.M. 2002. The anaphase-promoting complex: Proteolysis in mitosis and beyond. Mol. Cell 9: 931-943.

Peters, J.M., King, R.W., Hoog, C., and Kirschner, M.W. 1996. Identification of BIME as a subunit of the anaphase-promoting complex. Science 274: 1199-1201.

Pfleger, C.M. and Kirschner, M.W. 2000. The KEN box: An APC recognition signal distinct from the D box targeted by Cdh1. Genes \& Dev. 14: 655-665.

Pfleger, C.M., Lee, E., and Kirschner, M.W. 2001. Substrate recognition by the Cdc20 and Cdh1 components of the anaphase-promoting complex. Genes \& Dev. 15: 2396-2407.

Pickart, C.M. 2001. Mechanisms underlying ubiquitination. Annu. Rev. Biochem. 70: 503-533.

Pravtcheva, D.D. and Wise, T.L. 1996. A transgene-induced mitotic arrest mutation in the mouse allelic with Oligosyndactylism. Genetics 144: 1747-1756.

Schaffer, A.A., Aravind, L., Madden, T.L., Shavirin, S., Spouge, J.L., Wolf, Y.I., Koonin, E.V., and Altschul, S.F. 2001. Improving the accuracy of PSI-BLAST protein database searches with composition-based statistics and other refinements. Nucleic Acids Res. 29: 2994-3005.

Schwab, M., Neutzner, M., Mocker, D., and Seufert, W. 2001. Yeast Hct1 recognizes the mitotic cyclin $\mathrm{Clb} 2$ and other substrates of the ubiquitin ligase APC. EMBO J. 20: 51655175 .

Shirayama, M., Toth, A., Galova, M., and Nasmyth, K. 1999. $\mathrm{APC}(\mathrm{Cdc} 20)$ promotes exit from mitosis by destroying the anaphase inhibitor Pds1 and cyclin Clb5. Nature 402: 203 207.

Sigrist, S.J. and Lehner, C.F. 1997. Drosophila fizzy-related down-regulates mitotic cyclins and is required for cell proliferation arrest and entry into endocycles. Cell 90: 671-681.

Silver, D.P. and Livingston, D.M. 2001. Self-excising retroviral vectors encoding the Cre recombinase overcome Cre-mediated cellular toxicity. Mol. Cell 8: 233-243.

Stroschein, S.L., Bonni, S., Wrana, J.L., and Luo, K. 2001. Smad3 recruits the anaphase-promoting complex for ubiquitination and degradation of SnoN. Genes \& Dev. 15: 2822-2836.

Sudakin, V., Ganoth, D., Dahan, A., Heller, H., Hershko, J., Luca, F.C., Ruderman, J. V., and Hershko, A. 1995. The cyclosome, a large complex containing cyclin-selective ubiquitin ligase activity, targets cyclins for destruction at the end of mitosis. Mol. Biol. Cell 6: 185-197.

Sudo, T., Ota, Y., Kotani, S., Nakao, M., Takami, Y., Takeda, S., and Saya, H. 2001. Activation of Cdh1-dependent APC is required for $G_{1}$ cell cycle arrest and DNA damage-induced $\mathrm{G}_{2}$ checkpoint in vertebrate cells. EMBO J. 20: 6499-6508.

Tang, Z., Li, B., Bharadwaj, R., Zhu, H., Ozkan, E., Hakala, K., Deisenhofer, J., and Yu, H. 2001. APC2 cullin protein and APC11 RING protein comprise the minimal ubiquitin ligase module of the anaphase-promoting complex. Mol. Biol. Cell 12: 3839-3851.

Tannour-Louet, M., Porteu, A., Vaulont, S., Kahn, A., and Vasseur-Cognet, M. 2002. A tamoxifen-inducible chimeric Cre recombinase specifically effective in the fetal and adult mouse liver. Hepatology 35: 1072-1081.

Tugendreich, S., Tomkiel, J., Earnshaw, W., and Hieter, P. 1995. $\mathrm{CDC} 27 \mathrm{Hs}$ colocalizes with $\mathrm{CDC} 16 \mathrm{Hs}$ to the centrosome and mitotic spindle and is essential for the metaphase to anaphase transition. Cell 81: 261-268.

Visintin, R., Prinz, S., and Amon, A. 1997. CDC20 and CDH1: A family of substrate-specific activators of APC-dependent proteolysis. Science 278: 460-463.

Wan, Y. and Kirschner, M.W. 2001. Identification of multiple $\mathrm{CDH} 1$ homologues in vertebrates conferring different substrate specificities. Proc. Natl. Acad. Sci. 98: 13066-13071.

Wan, Y., Liu, X., and Kirschner, M.W. 2001. The anaphase-promoting complex mediates TGF- $\beta$ signaling by targeting SnoN for destruction. Mol. Cell 8: 1027-1039.

Wildpaner, M., Schneider, G., Schleiffer, A., and Eisenhaber, F. 2001. Taxonomy workbench. Bioinformatics 17: 1179-1182.

Yu, H., Peters, J.M., King, R.W., Page, A.M., Hieter, P., and Kirschner, M.W. 1998. Identification of a cullin homology region in a subunit of the anaphase-promoting complex. Science 279: 1219-1222.

Zachariae, W., Shin, T.H., Galova, M., Obermaier, B., and Nasmyth, K. 1996. Identification of subunits of the anaphasepromoting complex of Saccharomyces cerevisiae. Science 274: 1201-1204.

Zachariae, W., Schwab, M., Nasmyth, K., and Seufert, W. 1998a. Control of cyclin ubiquitination by CDK-regulated binding of Hctl to the anaphase promoting complex. Science 282: 1721-1724.

Zachariae, W., Shevchenko, A., Andrews, P.D., Ciosk, R., Galova, M., Stark, M.J., Mann, M., and Nasmyth, K. 1998b. Mass spectrometric analysis of the anaphase-promoting complex from yeast: Identification of a subunit related to cullins. Science 279: 1216-1219. 


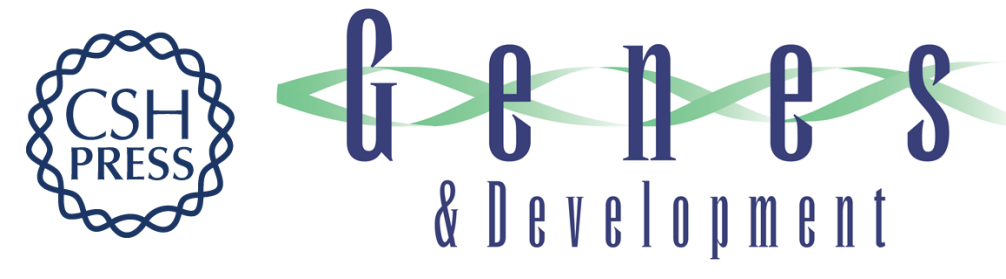

\section{Loss of the anaphase-promoting complex in quiescent cells causes unscheduled hepatocyte proliferation}

Karin G. Wirth, Romeo Ricci, Juan F. Giménez-Abián, et al.

Genes Dev. 2004, 18:

Access the most recent version at doi:10.1101/gad.285404

Supplemental http://genesdev.cshlp.org/content/suppl/2013/07/02/18.1.88.DC1
Material

References This article cites 47 articles, 26 of which can be accessed free at: http://genesdev.cshlp.org/content/18/1/88.full.html\#ref-list-1

License

Email Alerting

Receive free email alerts when new articles cite this article - sign up in the box at the top Service right corner of the article or click here.

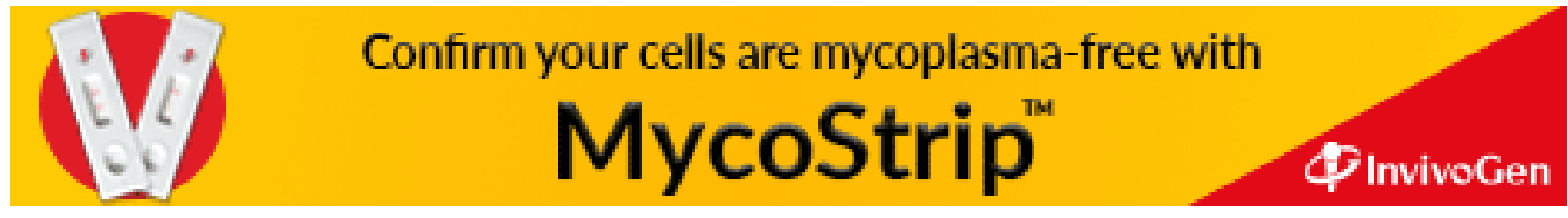

